\title{
EARWIGS OF THE \\ CALIFORNIA CHANNEL ISLANDS, WITH NOTES ON OTHER SPECIES IN CALIFORNIA (DERMAPTERA)*
}

\author{
By SCott E. Miller \\ Museum of Comparative Zoology \\ Harvard University \\ Cambridge, Mass. 02138
}

\begin{abstract}
Although the earwigs of the California Channel Islands were included in Langston and Powell (1975) and Langston and Miller (1977), newly accumulated records extend their distributions significantly (Table 1). Some of these new records are due to increased collecting activity by interested entomologists, but most probably represent range expansion by the earwigs, aided by increased human activity on the islands. The two species involved, Euborellia annulipes (Lucas) (Carcinophoridae) and Forficula auricularia Linnaeus (Forficulidae), are both considered to be introduced to California (Langston and Powell 1977). The two are readily distinguished by the shape of the forceps (Langston and Powell 1977: figs. 3, 11), as well as the adults being wingless ( $E$. annulipes) or winged ( $F$. auricularia). This note is based on the collections of the California Academy of Sciences (CAS), Natural History Museum of Los Angeles County (LACM), Peabody Museum of Yale University, San Diego Natural History Museum (SDNHM), Santa Barbara Museum of Natural History (SBMNH), Smithsonian Institution (USNM), and University of California at Berkeley (UCB), as well as my own fieldwork on all islands from 1976 to 1984.
\end{abstract}

\section{Euborellia annulipes (Lucas)}

This cosmopolitan species has been established in coastal southern California since at least the 1880s (Langston and Powell 1977). Channel Islands records are as follows: Santa Rosa: A single female was taken in July 1939 (LACM). A colony was found at Johnsons Lee in May 1977 (SBMNH). Santa Catalina: A series was collected at Avalon in October 1908 (USNM), but recently only single indi-

*Manuscript received by the editor June 26, 1984. 
viduals have been collected at Catalina Harbor (July 1979, LACM) and on the beach at Toyon Bay (May 1981, SBMNH). San Clemente: A series was collected in 1885 or 1886 by T.L. Casey (USNM), one was collected in November 1941 (LACM), and it has been taken in the 1970s around Wilson Cove (military living compound) and the new airport.

\section{Forficula auricularia Linnaeus}

This cosmopolitan species has not been established in California as long as E. annulipes and has undergone rapid expansion of range in the state in the last fifty years (Langston and Miller 1977). It was probably not established in coastal southern California until at least the 1940s (Langston and Powell 1975). Channel Islands records are as follows: Santa Rosa: Colonies sampled during the 1970s at Beechers Bay (ranch headquarters), Arlington Canyon, and Wreck Canyon (CAS, SBMNH, USNM). Santa Cruz: Powell (1981) discusses the establishment of this species between the late 1960s and 1978. It is now well established in the Central Valley. Santa Catalina: Between 1975 and 1983, it has been collected at Catalina Harbor, Cherry Cove, Cottonwood Canyon, Gallaghers Beach, Parsons Landing, Twin Harbors (Cat Harbor), and Toyon Bay (LACM, SBMNH), and can be very abundant (S.G. Bennett pers. comm.). San Nicolas: Taken in 1980 and 1982 at the military living compound (LACM, SBMNH). San Clemente: First taken at the new airport in March 1972 (UCB), it was taken at Wilson Cove and Lemon Tank in December 1981 (SBMNH). Santa Barbara: One female taken in June 1983 (LACM).

\section{Discussion}

Both species are generally restricted to the areas around human activity (i.e. ranch and military facilities) and beaches. The earwigs are omnivorous, sometimes predaceous on other insects, often feeding on live or dead vegetation, often injuring crops on the mainland (Langston and Powell 1975). These species, especially Forficula auricularia, can also be household nuisance pests, and can cause considerable annoyance in large numbers.

Based on the data presented above, E. annulipes has been present on three islands for 40 to 100 years and maintains small popula- 
Table 1. Summary of earwig distribution on the California Channel Islands.

\begin{tabular}{lcc}
\hline Island & $\begin{array}{c}\text { Euborellia } \\
\text { annulipes }\end{array}$ & $\begin{array}{c}\text { Forficula } \\
\text { auricularia }\end{array}$ \\
\hline San Miguel & $\mathrm{X}$ & $\mathrm{X}$ \\
Santa Rosa & & $\mathrm{X}$ \\
Santa Cruz & $\mathrm{X}$ & $\mathrm{X}$ \\
Anacapa & & $\mathrm{X}$ \\
Santa Catalina & $\mathrm{X}$ & $\mathrm{X}$ \\
San Nicolas & & $\mathrm{X}$ \\
San Clemente & & \\
Santa Barbara & &
\end{tabular}

tions, probably near the sites of initial introduction by man. $F$. auricularia, however, has apparently become established on six islands, mostly during the 1970s. It has not yet been recorded from San Miguel and Anacapa islands, but should be expected there. The agencies which administer the islands should attempt to discourage the rapid expansion of $F$. auricularia, by preventing additional introductions and eradicating existing populations when possible.

\section{APPENDix}

The following are significant additions to Langston and Powell (1975) and Langston and Miller (1977): Following Brindle (1971) and Steinmann (1975), the proper name of Spongophora apicedentata Caudell is Vostox apicedentatus (Caudell). Euborellia femoralis (Dohrn), a new California record, was reported from Red Hill Marina, Calipatria, Imperial County, by Steinmann (1981). Forficula auricularia has been established in the San Diego area, new southern record in California, since at least the mid 1970s (specimens in SDNHM).

\section{ACKNOWLEDGEMENTS}

I thank the National Park Service, U.S. Navy, Santa Cruz Island Co., Vail and Vickers Co., and Santa Catalina Island Conservancy for permission to collect on the islands; those and the Catalina Island Marine Institute, Santa Barbara Museum of Natural History, Southern California Academy of Sciences, TRW, and the 
University of California at Santa Barbara Marine Science Institute for logistic and financial support of surveys; the curators of the collections consulted; and S.G. Bennett, P.W. Collins, F.G. Hochberg, C.L. Hogue, R.W. Klink, R.L. Langston, C.D. Nagano, J.A. Powell, H. Steinmann, and D.B. Weissman for specimens and assistance.

\section{Literature Cited}

Brindle, A.

1971. A revision of the Labiidae (Dermaptera) of the Neo-tropical and Nearctic Regions. III. Spongiphoridae. J. Nat. Hist. 5: 521-568.

LANGSTON, R.L. AND S.E. MiLLER

1977. Expanded distribution of earwigs in California (Dermaptera). Pan-Pac. Ent. 53: 114-117.

Langston, R.L. AND J.A. Powell

1975. The earwigs of California (Order Dermaptera). Bull. Calif. Ins. Surv. 20: $1-25$.

Powell, J.A.

1981. Five insects believed to be newly established or recolonized on Santa Cruz Island, California (Dermaptera, Lepidoptera). Bull. Soc. Calif. Acad. Sci. 79: 97-108, (1980).

SteinmanN, $\mathrm{H}$.

1975. A Survey of the Neotropical Vostox Burr species (Dermaptera: Labiidae). Acta Zool. Acad. Sci. Hung. 21: 435-445.

1981. A study of the circumtropical Dermaptera material in the "Instituut voor Taxonomische Zoologie", Amsterdam. Acta Zool. Acad. Sci. Hung. 27: 187-210. 

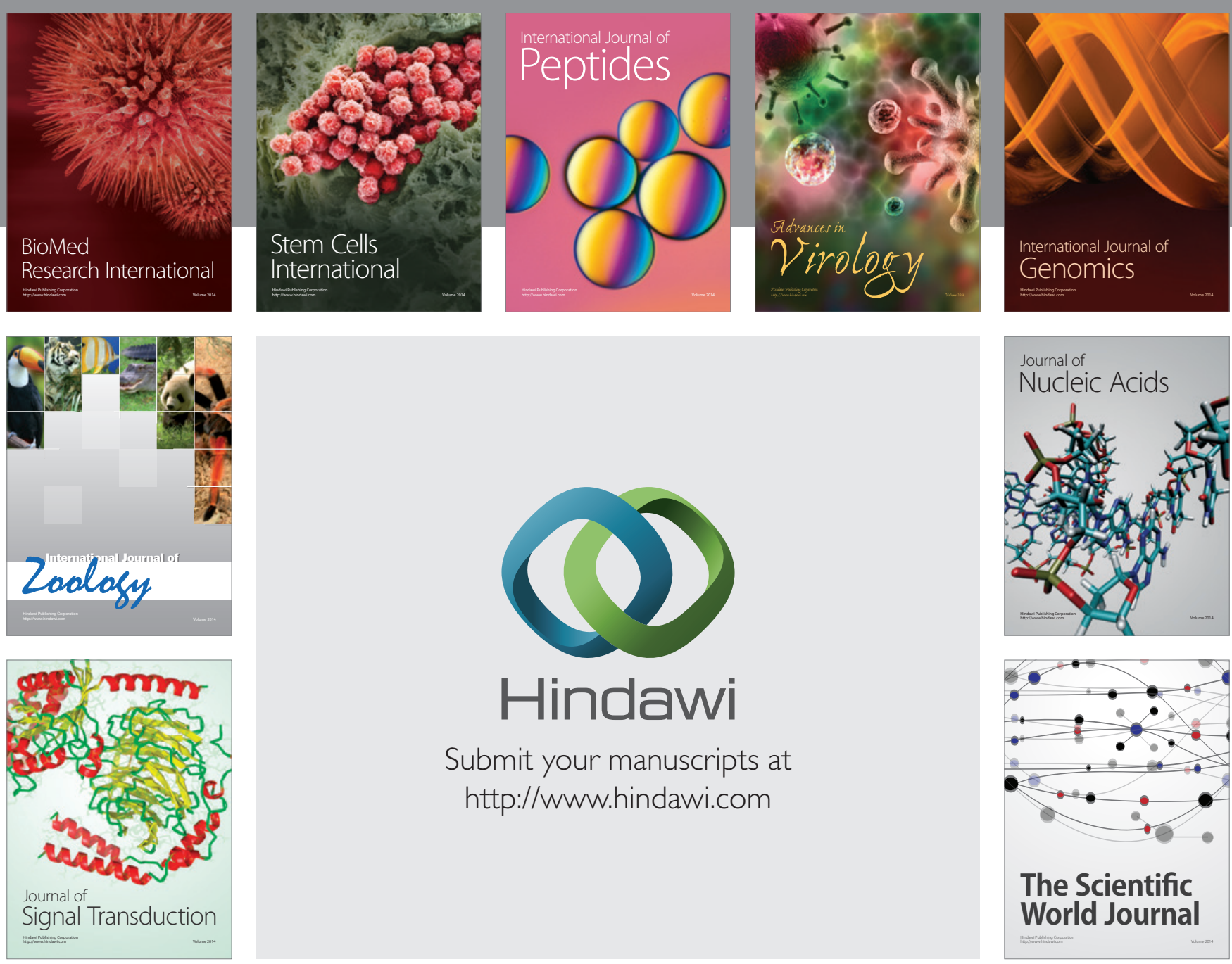

Submit your manuscripts at

http://www.hindawi.com
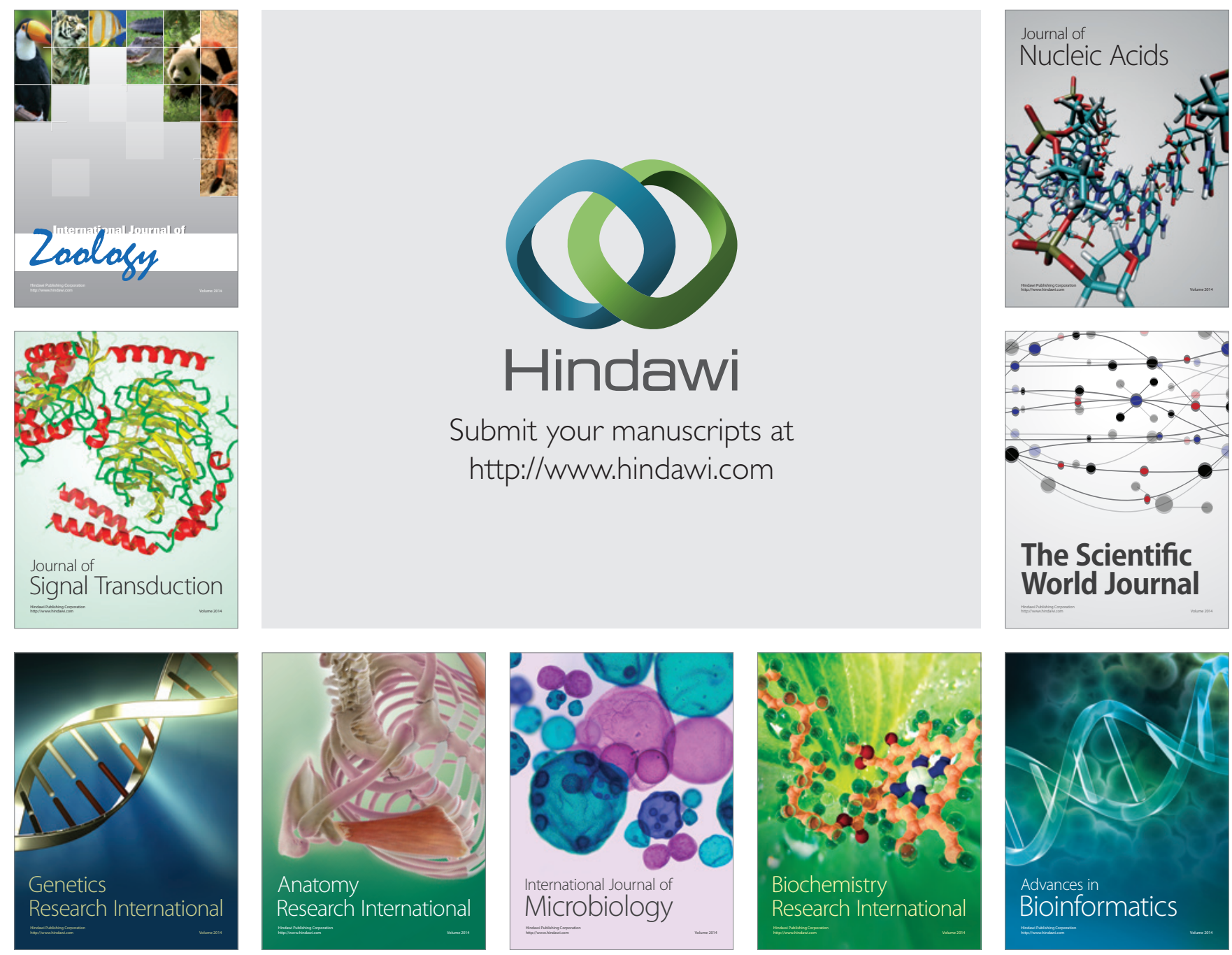

The Scientific World Journal
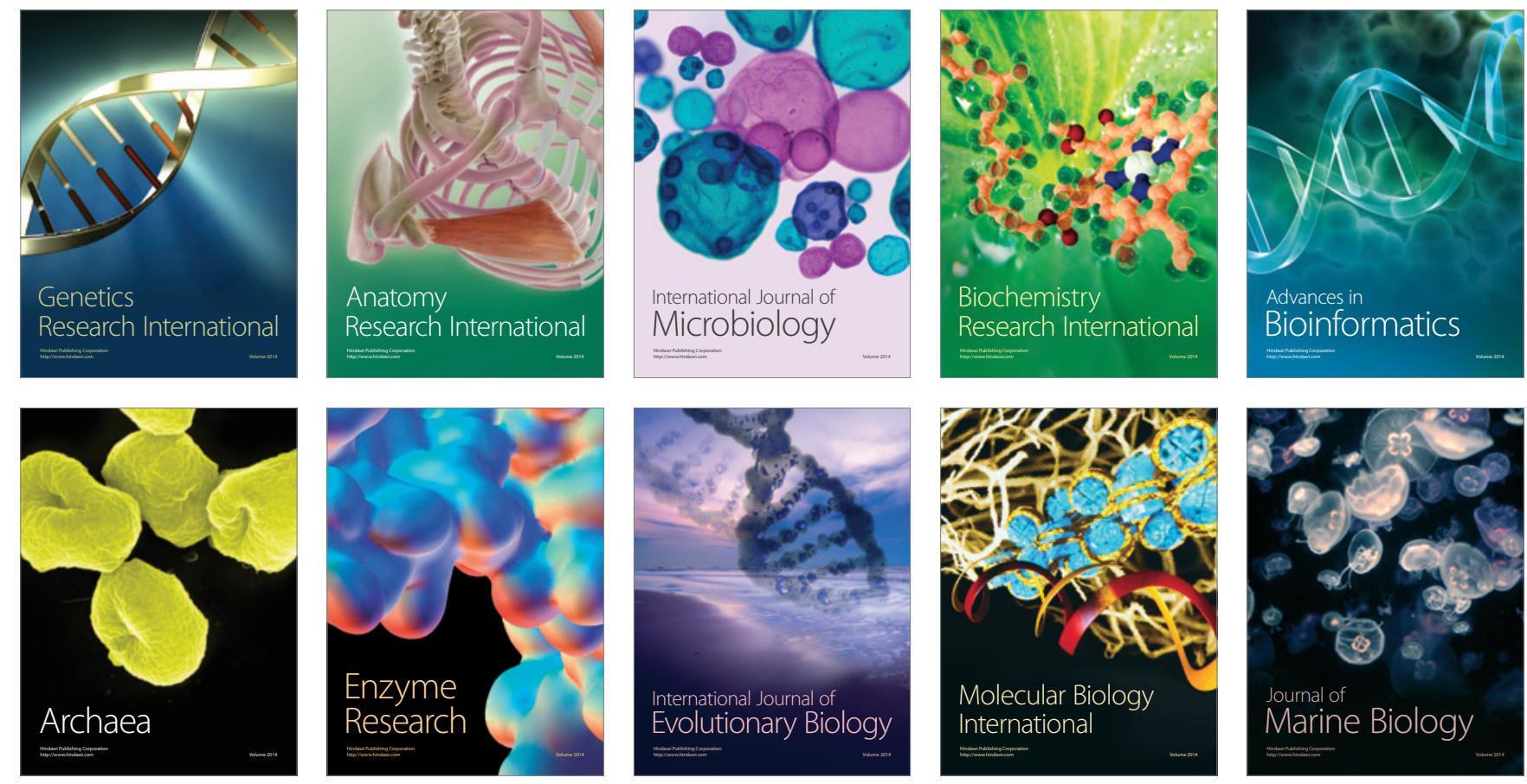